\title{
Village Forest Management Rights as Tourism Forests in Buleleng: A Coexistence Concept Perspective
}

\author{
I Made Suwitra ${ }^{1}$, I Wayan Wesna Astara ${ }^{2}$, I Wayan Rideng ${ }^{3}$ and I Ketut Kasta Arya Wijaya ${ }^{4}$ \\ \{madesuwitra@yahoo.co.id ${ }^{1}$,wesna_astara@yahoo.com², wayan_rideng@yahoo.co.id ${ }^{3}$ and \\ kastaaryawijaya@gmail.com ${ }^{4}$ \\ Universitas Warmadewa, Denpasar-Bali, Indonesia
}

\begin{abstract}
This study introduces and highlights the concept of coexistence between state law and customary law in village forest management in Bali. By this, we utilize the concept of coexistence to reveal the rights of Village Forest management. The design of the study is normative study design. As forests are the strong resources for community life in Bali, sustainable maintenance of the village forests are our implied objective in order to allow the community to gain benefits from the crops for a better life. Normatively, there is duplication of norms and interest in the provision and implementation of Village Forest management rights and the existence of customary rights of indigenous communities, so that coherence and correspondence are necessary in granting authority to villages, both form the Law called Desa Keperbekelan and the traditional (customary) village called Desa Pakraman.
\end{abstract}

Keywords: Coexistence; legal assurance; tourism; village forest management

\section{Introduction}

Forest damage in North and West Bali, such as in Buleleng, has become increasingly alarming [1] [2], [3]. In addition to the rampant theft of forest timber (illegal logging), there is a practice of buying and selling forest land by irresponsible individuals. While supervision by forest rangers is not optimal because of the limited number of personnel and the lack of infrastructure in the field. The results of the Working Visit of the Commission II of the Regional Parliament of Buleleng at the Office of the Forest Management Unit (KPH) of West Bali concluded that it was true that timber theft had taken place, such as land sale and purchase transactions, as happened in Sepang Busungbiu Village. The reason is very cliché, namely that personnel are very minimal, operational vehicles are very limited. Therefore, innovation is needed to create new patterns in management and utilization. [4]

According to Suwitra, et al stated that the control of forest areas in several Indigenous Villages/Pakraman Villages in Bali is based on customary rights, namely as in Culik Customary Village, Tenganan Pegringsingan Village Karangasem. With the enactment of "Act No.5 of 1960 concerning Basic Agrarian Law (BAL) "had given the possibility of transfer of tenure rights according to customary law towards control or acquisition according to State law ("BAL") [5]. The implication is that the existing ulayat lands in the forest area are transferred to individual or communal/group ownership rights, as happened in the Culik Customary Village which implies a prolonged conflict. Disputes caused by the sale and purchase of customary land can also be found in the Gianyar Indigenous Peoples Village which is caused by the denial of the Prajuru Desa Adat (the leader of customary village) to the results of the 
paruman (meeting) who have allowed the transfer of customary land into individual land. Then there is an effort from the prajuru adat party in the use of the land even though the person concerned has willingly carried out the obligation in the form of "ayahan" which attaches the land to the traditional village. [6]

In contrast to the management of forests by the traditional village in Tenganan Pegringsingan Karangasem as the customary right of the customary law community called Desa Pakraman based on "Bali Provincial Regulation No. 3 of 2001 jo No. 3 of 2003 ". The area of forest as a customary land of Pakraman (customary) Village reaches 712.2 hectares. The condition is still sustainable and there is no theft, because the customary law community adheres to the myth that the ulayat land in the form of forest is guarded by a supernatural being called Lelipis Lembukit and will give punishment that is pegged snake to anyone who commits theft of wood and other forest products [7].

This study is aimed to analyze the certainty and fairness of the rights to manage and utilize Village Forests that are packaged as tourism forests by village institutions perspective on the concept of coexistence in the legal system. While the benefits are can be used as a policy basis by the Regional Government and Village Government in managing and utilizing Village Forests to achieve mutual prosperity.

The type of research used is normative legal research, because it is alleged that there are vague of norms in village forest management, even duplication of norms can occur as a result of sectoral ego and mutual authority between legal structures, resulting in inconsistencies in the regulation and issuance of permits. Village Forest management and utilization. Research problems will be approached through statute approaches, concept approaches, and customary law approaches. Data collected by documentation and recording techniques through the file system and analyzed by hermeneutic techniques. The expected outcome is the construction of the concept of "coexistence" in the legal system by remembering the diversity of Indonesian people with their respective customary laws.

\section{Discussion}

\subsection{Legal Norms Inconsistence in Village Forest Management}

In "Act No. 41 of 1999 (Act 41/1999) in conjunction with Act Number 1 of 2004 (Act 1/2004) concerning Amendments to Act Number 41 of 1999" dividing the status of forests into State Forests and Private Forests. While in the State Forest can be in the form of Customary Forests. It is relevant to the concept affirmed in the general provisions of this Law, that customary forests are state forests within the territory of customary law communities. existence and recognition of its existence, and not in conflict with national interests ("Article 4 Section 3"). This condition indicates that there is a domination of the State law on customary law. The existence of this customary forest is highly dependent on the existence of the existence of indigenous law communities which are further regulated through Regional Regulations ("Article 67 Section 2") [8]. For specific purposes forest management areas can be given to customary law communities with the following rights, namely:

a. collecting forest products to fulfill the daily needs of the indigenous peoples concerned;

b. conduct forest management activities based on customary law in force and do not conflict with the Law; and

c. obtain empowerment in order to improve their welfare 
In fact, customary forest claims by customary communities as their customary rights often cause conflict because there is domination of state law in forest management, as in the case of Masuji in Lampung, forest encroachment in West Buleleng, acquisition of customary land by the government without released by indigenous law communities in Papua relating to compensation.

The 2015-2019 National Medium Term Development Plan, targets 12.7 million Ha of forest to be managed by the community through a social forestry scheme, one of which is Village forest. Village Forest is a State forest that is managed by the community in a rural organization. And it is utilized for the welfare of the Village community itself. According to Titian (2016), the village forest intends to provide access to the community through village institutions in utilizing forest resources sustainably. In hopes of improving the welfare of local communities in a sustainable manner [9].

Based on recalculation data from the 2014 Indonesian Land Cover Closure by the Directorate of Forestry Planning and Environmental Management (Ministry of Environment and Forestry 2015), it is known that the forest land area on the island of Bali is 127.3 thousand Ha or about $22.5 \%$ of the land area of Bali province. Of the total area, only 86.3 thousand hectares or about $2 / 3$ of them have land cover in the form of forests. In the context of spatial planning must be based on several principles, such as integration, sustainability, togetherness and partnership, harmony, harmony, balance, legal certainty. In the preparation of social forestry in the regions of Java, Bali and Nusa Tenggara by the Office of the Social Forestry and Environmental Partnership Center since 2015, the task is to prepare social forestry areas, business development and partnerships and conflict mapping in the Social Forestry and Environmental Partnership fields [10].

Observing the existence of very different conditions in forest management according to state law in West Bali with forest management according to customary law in Adat Village in Tenganan Pegringsingan Karangasem indicates that customary community-based forest management is more effective than forest management according to state law in terms of its supervision. Therefore, it seems that the model of forest management based on social forestry such as village forests will be able to harmonize aspects of supervision in forest utilization through the concept of coexistence in the legal system [6].

Several villages in Buleleng Regency have been established in managing village forest by empowering village communities around to improve forest quality and community economy. One of the protected forest areas in Selat Village, Sukasada sub-district covering 552 hectares has been designated as a Village Forest work area based on "Decree of the Minister of Forestry of the Republic of Indonesia Number: SK.629/Menhut-II/2010" dated November 11, 2010.Then Permit for Village Forest Management (HPHD ) just issued on December 11, 2015 based on "Bali Governor's Decree No. 2017/03-L/HK/2015 "concerning Granting Village Forest Management Rights in Protected Forest Areas covering an area of approximately 3,041 hectares to 7 (seven) Village Institutions in Buleleng Regency. Titian further stated that the people in several villages within the Production Forest Management Unity model of Sintang District, Titian Lestari Foundation together with Production Forest Management Unity Marakai Sintang Model carried out the socialization of regulations on forms of community forest management [11].

The Government of Indonesia through the "Regulation of the Minister of Forestry of the Republic of Indonesia No: P.89/Menhut-II/2014 (Permenhut P.89/2014)" Regarding Village Forests, provides opportunities for rural communities to manage forests in the village with the aim of improving community welfare locally sustainably and ensure the preservation of the 
environment. This opportunity should be interpreted properly and correctly in order to be able to provide maximum welfare [12].

The issuance of permits and Village Forest management rights from the Ministry of Forestry and the Governor to date are only intended for Villages according to "Act No.6 of 2014". In addition, the laws and regulations governing forests such as "Act No.41 of 1999" jo "Act No. 1 of 2004 concerning Amendments to Act No. 41 of 1999 "concerning Forestry divides the status of forests into state forests and customary forests. This law also formulates, that in state forests also include customary forests. Although later this provision has been corrected through "Decision of the Constitutional Court (MK) Number 35/PUU-X/2012" dated May 26, 2013 with several assertions relating to the existence of the Ulayat Rights of Customary Law Community especially towards the existence of Customary Forest in the Judicial Review Material "Act Number 41 Year 1999 ". The decision of the Constitutional Court has annulled the contents of" Act Number 41 Year 1999 "which denies customary forests, and reaffirms that customary forests must be recognized by stipulation as long as in reality they still exist. It must be distinguished between customary forests and individual forests/legal entities. So customary forests are not included in the state forest category. Therefore recognition and respect for the existence of customary rights in the Customary Law Community again references the provisions of "Article 18 B Section (2) of the 1945 Constitution of the Republic of Indonesia [8].

In an effort of reducing poverty, unemployment and inequality in forest area management/utilization, Social Forestry activities are needed through efforts to provide legal access to local communities in the form of Village Forest Management, Community Forest Business Licenses, Community Plantation Forests, Forestry Partnerships or recognition and protection of indigenous peoples for the welfare of the community and the preservation of forest resources. For this reason it was issued "Regulation of the Minister of Environment and Forestry of the Republic of Indonesia No: P.83/MENLHK/SETJEN/KUM.1/10/2016 concerning Social Forestry."[13]

Social forestry is conceptualized as a sustainable forest management system implemented in State forest areas or customary forest/forest rights carried out by local communities or customary law communities as the main actors to improve their welfare, environmental balance and socio-cultural dynamics in the form of Village Forests, Community Forests, Community Plantation Forest, Community Forest, Customary Forest and Forestry Partnership [13].

Village Forest is a State forest that is managed by the village and utilized for village welfare. While the Village Forest Management Rights are management rights in protected forest areas or production forests that are given to village institutions, namely village social institutions tasked with managing Village Forests. In "Government Regulation (PP) No. 43 of 2014 concerning the Implementation Regulation of Act No.6 of 2014 concerning Villages "stated that village social institutions were formed on the initiative of the Village Government and the community (" Article 150 section 1 "). The tasks are: (a) empowering rural communities, (b) participating in development planning and implementation; and (c) improve the service of the village community ("Article 150 section 2"). Its formation is governed by the Village Regulation. Village Institutions that manage Village Forests can take the form of cooperatives or local village-owned enterprises. The form of a business entity that was developed as a Village Institution that manages the Village Forest today in 7 (seven) Village Institutions who hold a Village Forest management permit in Buleleng is a "Village-Owned Enterprise" ("BUMDesa") or better known as "BUMDes " [14] 
This Village Forest management permit is stipulated in the "Governor of Bali Decree No 2017/03'L/HK/2015 concerning Granting Village Forest Management Rights in $\pm 3,041$ Hectares of Protected Forest Areas to 7 (seven) Village Institutions in Buleleng Regency" jo Minister of Forestry Decree Republic of Indonesia Number: SK.629/Menhut-II/2010 concerning Determination of Regions as Village Forest Work Areas covering $\pm 3,041$ (three thousand forty one) Hectares in Buleleng Regency, Bali Province. The distribution of Protected Forest areas as Village Forest work areas in the administrative area is as follows:

Table 1. Protected Areas as Village Forests.

\begin{tabular}{llll}
\hline No. & Village Name & Sub-Districts & Area/Hectares \\
\hline 1 & Selat Village & Sukasada & 552 \\
2 & Wanagiri Village & Sukasada & 250 \\
3 & Sudaji Village & Sawan & 90 \\
4 & Lemukih Village & Sawan & 988 \\
5 & Galungan Village & Sawan & 712 \\
6 & Telaga Village & Busungbiu & 96 \\
7 & Tejakula Village & Tejakula & 353 \\
\hline
\end{tabular}

Village Institutions as Village Forest managers have the right to: (a) manage the Village Forest Work Area in the form of area utilization, use of environmental services and collection of Non-Timber Forest Products (Indonesian term is HHBK) in accordance with the Work Plan, (b) get assistance, (c) get facilitation in Forest management Village. In addition to the rights, obligations were also obeyed, namely: (a) implementing boundaries for Village Forest Management Rights, (b) preparing Village Forest Management Plans, (c) carrying out forest protection in the working area of Village Forests and surrounding areas, (d) carrying out rehabilitation of work areas Village Forest, (e) carry out planting and other activities in accordance with the work plan, (f) cultivate crops in accordance with applicable site conditions and legislation, $(\mathrm{g})$ carry out the administration of forest product utilization in accordance with the prevailing laws and regulations and (h) make a report on Village Forest management [15].

The Village Forest Management Plan is prepared by the Village Institute in a participatory manner with the local Forest Management Unit and approved by the Head of the Bali Provincial Forestry Service which contains: (a) the work plan for the Village Forest Management Rights for the period of the Village Forest Management Rights, which is 15 years, (b) Village Forest work plan for a period of 10 years, and (c) annual plan of the Village Forest for a period of 1 year. The Management Plan material includes: plan for the management of the protected area, plan for the management of the utilization area, the business plan that is accompanied by a map of 1: 10,000 scale.

The Management Permit also affirms the prohibition on Village Institutions in managing Village Forests, namely: carrying out forest destruction in the form of cutting trees and changing landscapes, transferring or aggregating and changing the status and function of forest areas, using forest areas for other purposes outside the Village Forest Management Plan.

As a guidance, supervision and control material as well as extension of Village Forest Management Rights, evaluation is made at the latest every 2 years with the consequence that Village Forest Management Rights can be abolished if: the period of Village Forest Management Rights has ended, the Village Forest Management Rights are revoked by the Governor if Rights holders do not fulfill the rights and obligations as stipulated, Village Forest management rights are handed back by the right holder with a written statement to the Governor before the term of management rights expires, or the holder of the Village Forest 
Management cannot fulfill the obligations as stipulated. Observing various legal norms in the management of "Village Forest" can be analyzed duplication and inconsistency of norms between the rules above with the rules below, so as not to fulfill legal certainty, which is relevant to the Certainty of Gustav Radbruch Theory which distinguishes certainty due to law, and legal certainty or self. Certainty in law is achieved if there is no contradictory provision in the Law because it is based on rechtswerkelijheid (legal reality) and there are no legal terms that can be interpreted differently. Whereas certainty due to the law is intended, that the law guarantees certainty to one party to another party. The conclusions of the analysis are based on observations, that there is a disclaimer on the management rights of customary law communities, namely Pakraman Village, because management rights are only given to Village Institutions which are in fact formed by Desa Dinas (Administrative Village). While in the Forestry Act it provides opportunities for indigenous and tribal peoples in forest management for welfare, namely as stated in ("Article 67 of Act No. 41 of 1999"). In addition, Protected Forests are conceptualized in "Act No. 41 of 1999 "this is a forest area that has a basic function as protection of life support systems to regulate water management, prevent flooding, control erosion, prevent sea water intrusion, and maintain soil fertility, then can be designated as utilization forest as stipulated in the" Governor Decree No 2017/03-L/HK/2015 "keeping in mind the rights and obligations, restrictions and evaluations. In order to have consistency, it is necessary to change the status of forests from protected forests to utilization or production forests before being designated as Village Forests.

In the perspective of the time limit for granting Village Forest Management Rights, which is limited to a minimum of 15 years and will be evaluated at least every 2 years, is not relevant and inconsistent with the provisions "Article 2 section 4 of Act No. 5 of 1960 concerning Basic Agrarian Principles (BAL) "formulates: The right to control from the above countries can be authorized to the Swatantra regions and customary communities, only necessary and not in conflict with national interests, according to the provisions of the Regulation Government. This means that the granting of Management Rights to the Regional Government as a Swatantra Region which later becomes a regional asset land, can also be applied mutatis mutandis to Pakraman Village as a customary law community, so that there is no 15 years time limit. But the implementation of the evaluation at the latest every 2 years can be accepted to avoid claims of ownership and alienation, as well as supervision of its use in the context of the preservation of environmental functions by considering the concept of sustainable development (Sustainable Development Goals).

The application of Village Forest in the Protected Forest area, from the aspect of the theory of "Utility Jeremy Bentham" namely conceptualizing the ability as the greatest happiness for the most people want to state. According to Bentham, the existence of state and law is solely for the sake of true benefits, namely the happiness of the majority of the people, which is relevant to the motto: the greatest happiness for the greatest number of people. Therefore, new construction is needed as a novelty in co-ordinating state law and customary law (society) in the legal system for the management of Village Forests. The hope is that it can contribute to the renewal of the Law of Social Sciences with regard to legal functions both as a social control and as a social engineering. So hierarchically, the legal norms under the Act must not conflict with legal norms above them to guarantee legal certainty, justice and benefits, namely welfare. It is relevant to President Joko Widodo's Nawacita, namely building from the outskirts (Village). One form is the granting of Village Forest Management Rights to Village Institutions.

In the perspective of justice, the determination of the granting of permits for Village Forest Management Rights is not in harmony with the Ulpianus justice theory which states 
that justice is a steady and constant will to give to each of its parts (Iustitia est constants et perpetua voluntas ius suum cuiquetribuendi). There is no constancy or consistency of normalization of various legal rules that have been established by the State. The management model attaches importance to rigid procedural, so that it is only relevant to John Rawls's theory of justice, namely "Justice as equality" which produces "pure procedural justice". [16] In pure procedural justice, there is no standard that can decide what is "fair" apart from the procedure itself. Justice is not applied to the outcome, but to the system. [17]

\subsection{Coexistence of State Law and Customary Law in Village Forest Management in Selat Village of Buleleng Regency}

Selat Village as one of the Old Village Villages in Sukasada Buleleng District borders with four matching villages, namely: North Side of Anturan Village, south of Gobleg Village, East of Tegalinggah Village, west of Kayu Putih Village. Its area is 1,206 hectares. This village is divided into seven Banjar Dinas with population density as shown in the table as follows:

Table 2. Population in each of the Banjar Dinas in 2015.

\begin{tabular}{llllll}
\hline No & Banjar Dinas & Number of family head & Male & Female & Number of people \\
\hline 1 & Tukad Juwuk & 170 & 407 & 384 & 551 \\
2 & Sekarsari & 228 & 501 & 500 & 1001 \\
3 & Gunung sekar & 288 & 629 & 639 & 1268 \\
4 & Gambuh & 383 & 875 & 839 & 1714 \\
5 & Bululada & 398 & 903 & 874 & 1777 \\
6 & Selat & 221 & 516 & 515 & 1031 \\
7 & Witajati & 170 & 401 & 381 & 782 \\
& Total & 1829 & 4108 & 4022 & 8130 \\
\hline
\end{tabular}

Source: 10 Years Work Plan of Selat Village Forest year 2016.

Based on the area of use, the Selat Village consists of around 26 hectares of residential areas, around 112 hectares of rice fields, around 169 hectares of plantations, and about 552 hectares of forest land and is a protected forest area and is the most extensive area. As time went on, the condition of the forest around the village changed significantly due to excessive forest exploitation by the surrounding community members and outside residents in order to meet their living needs. Changing forest conditions also decreased the function of the forest, such as reduced flow of water flowing into the village. Aware of the decline in forest functions and concerns about the future of forests and the future of communities without forests, so that people begin to think and move to manage forests for conservation through groups. The formation of this group is the forerunner of the drive for sustainable forest management in the Selat Village.

These community groups are more excited by the issuance of "Decree of the Minister of Forestry of the Republic of Indonesia Number: SK.629/Menhut-II/2010" jo "Bali Governor Decree No 2017/03-L/HK/2015" concerning Granting Village Forest Management Rights to 7 (seven) Village Institutions in Buleleng Regency. Forms of Village Institutions in each Village, namely those known as Village-Owned Enterprises (BUMDes). In Selat Village it is called BUMDes (Village Owned Enterprise) Pandan Harum which was established on February 10, 2011. BUMDes is an independent institution owned by rural communities engaged in building forests for the welfare of the village community and preserving it as part of the ecological function of the forest which indirectly benefits the surrounding community. 
Relevant to the research of I Made Suwitra, et al (2017) concerning the Model of Management of Agrarian Resources Based on Tourism Villages and Local Legal Wisdom in Paksebali Klungkung Village, stated that the management of agrarian resources is carried out by the Service Government through a business entity which is currently called BUMDes. So that all aspects of the business are managed by BUMDes formed through Village Regulations (Perdes). The coexistence of Unda River surface water management is indeed necessary, because the management and licensing of surface water utilization is the authority of the Province in accordance with the mandate of the Bali Provincial Regulation No.3 of 2004.

The issuance of the Governor's Decree does not necessarily make BUMDes able to carry out its activities in managing Village Forests, but previously BUMDes are required to make Work Plans for one year, 10 years, and 15 years in a participatory manner with the local Forest Management Units. to be ratified by the Head of the Bali Provincial Forestry Service. The management plan is based on the initial potential of the forest area, so that the program implemented is sustainable. The planned programs to be implemented are shown in Table 3:

Table 3. Implemented Programs.

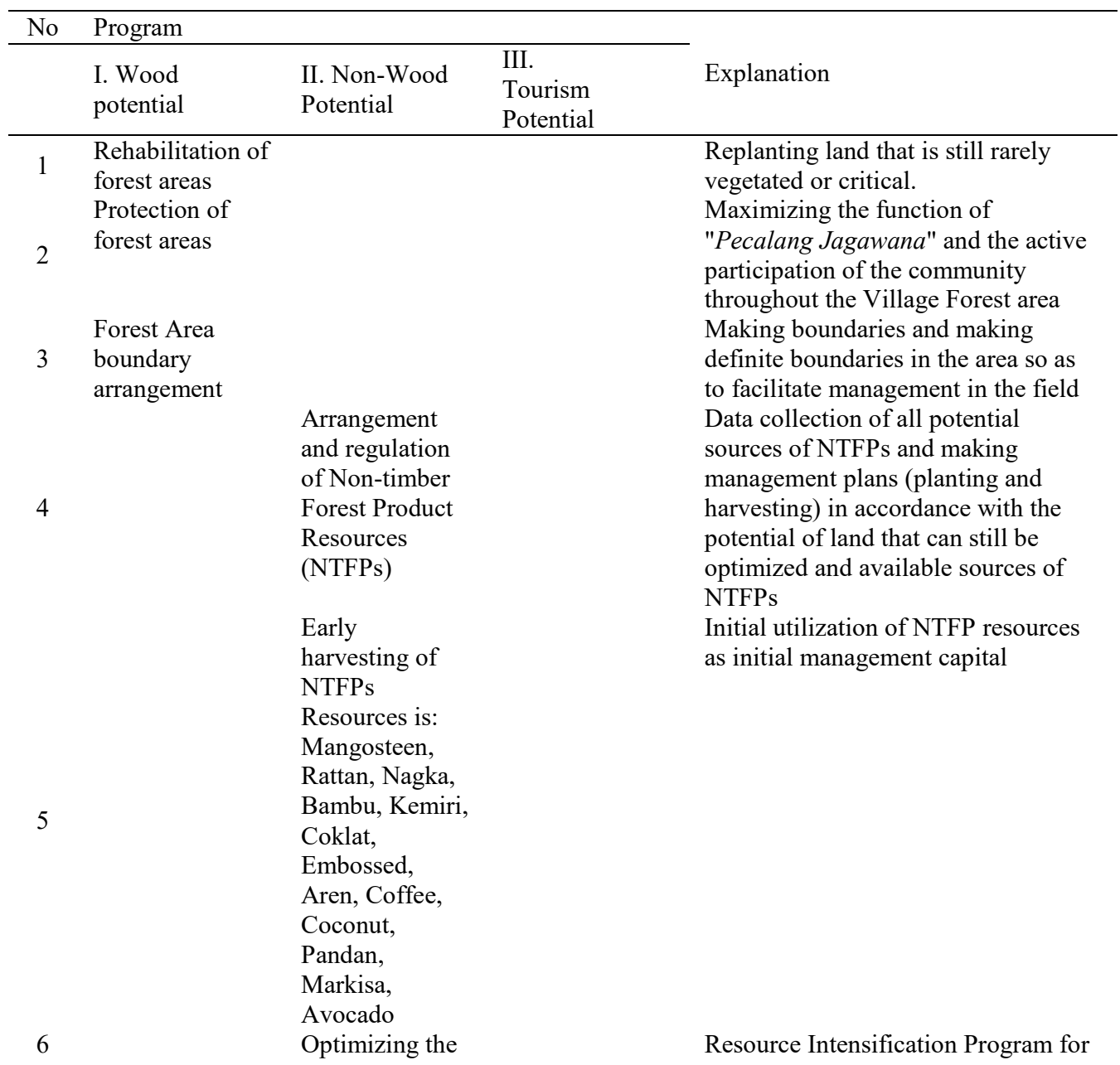


potential of NTFPs

\author{
Manufacture of \\ downstream \\ industries
}

Marketing of finished products of NTFPs

Initial arrangement of prospective tourism areas

Development of natural tourism areas Management of tourist areas
NTFPs in forest areas to increase NTFP yields by utilizing available land suitable for NTFP-producing growth

Make business units that develop NTFPs from Village Forest areas to finished products. The business unit is directly driven by farmer groups or local women farmers groups. The activity of marketing processed forest products to the local market and then will be expanded even further

Make preliminary preparations for making tourist areas to be built, both physical (accessibility, facilities and infrastructure) and non-physical (management material)

Build tourist areas both with their own capital independently and from third parties

Running existing tourism areas in accordance with the potential and supported by sufficient and integrated promotion

Source: The history of BUMDes (Village Owned Enterprise) Pandan Harum Selat Village Sukasada Subdistrict Buleleng.

Note: The total value of NTFP products that can be produced in one year: Rp. $19,615,101,667.00$

The Selat Village Forest will be focused on learning a community-based biodiversity learning center, which is as a joint learning in forest management and sustainable use of local plants. In addition, the management model is based on the Tri Hitakarana philosophy which is defined as the three causes of public welfare, which can be seen from the three forms of relationships in human life, namely Parhyangan (God) realize human relations with the Creator (Hyang Widhi Wasa), Palemahan (environment) embodies human relations with the natural environment in which they live. and Pawongan (human) embodies human relations with human beings created by Hyang Widhi Wasa (God).

Community-based Village Forest Management based on Tri Hitakarana's philosophy indicates that its management will be supported by the Village Customary Institution (in "Law No. 6 of 2014") which is referred to in Bali as Desa Adat, customary village, version "Bali Provincial Regulation No. 6 of 1986 ", and now called Desa Pakraman version" Bali Provincial Regulation No. 3 of 2001 "Jo" Regional Regulation No. 3 of 2003 ". Every Desa Pakraman has a customary law called Awig-Awig Desa that functions to create social order. Especially in securing the Village Forest is done by the "Forest Pecalang (traditional security) " or "Jaga Wana" which is responsible for maintaining the preservation of the Village Forest.

The Selat Village Forest as a protected forest function area dominated by topography sloping to steep, its quality decreases. If forest degradation supported by Desa Selat is allowed to continue, it has the potential to cause disasters especially floods, landslides, droughts and forest fires which have a very large socio-economic impact on the villagers and the people of Singaraja city. Therefore, assistance is needed through Forest and Land Rehabilitation by 
involving all stakeholders through a comprehensive system approach and taking into account the functions and status of the forest.

In the preparatory phase efforts were made to accelerate the rehabilitation of forest areas in 2005 by the District Government with a variety of rare plants that had grown to 450 hectares. While the villagers themselves began to declare forest areas as a buffer for food reserves by planting tubers such as Suweg, Uwi, Gembili years 2009. In additions it is planned to develop a medicinal plant called "Taru Premana" and also from the "Usada Bali" palm leaf. The community also has agricultural economic activities with coffee cultivation which creates opportunities to develop Civet coffee production.

The growing commitment of the Selat Village community to manage forests sustainably and utilize their functions according to the lives of the people is the concern of the Buleleng Regency Forestry and Plantation Service, so that the area of forest areas in Selat Village is followed to become Village Forest in 2009 which is designed as an empowerment process, namely in the form of increased knowledge and Community organizing skills are in planning, implementing and monitoring as a learning model of Village Forest management and sustainable use of local biological resources to promote the welfare of rural communities.

Conceptually, the community-based Village Forest management model with its local legal wisdom through the empowerment process indicates that there is coexistence in the legal system, namely the substance, structure and legal culture empirically. The existence of state law and customary law (Awig-Awig) as a form of legal substance, the existence of Forest Police and Forest Pecalang (Jaga Wana), and the existence of an empowerment process through education in forest security, indicates that there is a strong willingness to coexist the existing legal system. However, currently it is only limited to the use of "opportunities" that exist casuistically and has not been consistently based on a comprehensive initial design. It is relevant to the study of Caste and friends about Environment Dispute Resolution through Awig-Awig (Customary Law) (Case Study in Customary Community) of Tenganan Pagringsingan, Regency of Karangasem, Bali), that the participation of indigenous villages of Tenganan Pagringsingan on the maintenance of the continuous function of the environment is in the interest of the customary village community from the past has been good. Motivation of indigenous people Tenganan traditional village to maintain environmental sustainability is quite high. This is evidenced by what is contained in customary villages, as well as the active participation of reforestation in the village hilly areas periodically.

In the concept of legal system theory, there is a domination of state law, namely the substance of legal system, meaning that the regulation on the rights of village forest management is based on the "Decree of the Minister of Forestry of the Republic of Indonesia Number: SK.629/Menhut-II/2010" jo "Governor Decree Bali No 2017/03-L/HK/2015 "which does not provide an opportunity for the application of customary law (Awig-Awig). From the aspect of the structure of legal system, namely the institutional "Decree of the Minister of Forestry jo Decree of the Governor of Bali" clearly only appoints Community Institutions in the form of BUMDes (Administrative). Finally, from the aspect of culture of legal system, a pattern of behavior is formed which is directed to follow the pattern of state law, namely from planning, implementing, controlling and harvesting. All of them are made in a participatory manner with the local Forest Management Unit and approved by the Head of the Forestry Service of the Province of Bali and under its supervision.

In the design of the "shared" management concept through the "empowerment" process especially so that there is a change in the mindset of the community towards the existence, preservation for the sustainability of Village Forest resources, the empirical coexistence is incidental, namely the role of Forest Pecalang or Jaga Wana for safeguarding Village Forests. 
community culture to follow the pattern of state law (social engineering function) on the one hand, while on the other hand it is required the ability to translate the Tri Hitakarana philosophy according to current developments. While the coexistence of the substance of legal system aspect does not yet exist, because the regulation of Village Forest is only based on State law, namely "Decree of the Minister of Forestry of the Republic of Indonesia Number: SK.629/Menhut-II/2010" jo "Decree of the Governor of Bali No 2017/03-L/HK/2015 ".

In the utility perspective of Bentham theory, the results of management and utilization of Village Forest for a year amounting to Rp.19,615,101,667.00 (Nineteen billion six hundred and fifteen million serata one thousand six hundred sixty seven rupiah). This amount of income seems very large compared to village funds ranging from 1.5-2 (one half to two) billion. If this amount can be utilized by BUMDes (Village owned Enterprise) for the welfare of the village community, each village that manages the Village Forest through BUMDes will immediately be able to enjoy the benefits. The villagers will be more passionate and more aware of managing the Village Forest wisely as a sustainable forest for the development of utilization in the field of education and tourism such as visiting upakara or medicinal plantations, tracking Route, Waterfall, Religion, Meditation.

\section{Conclusions}

There is no consistency in normalization of Village Forest management, the consequence is there is no legal certainty in its management, so normalization is needed. In additions there is no coexistence design in the legal system, but the involvement of the Awig-Awig structure is only casuistic because the involvement of the legal structure in new customary law is carried out when the existence of the legal structure in State law lacks support from the public, so it needs to avoid the domination of state law against the law custom. Community-based management with an empowerment model needs to be developed so that it can be used as an evaluation material for the concept of coexistence in order to be able to arouse public awareness in utilizing forest resources for mutual benefit and sustainability.

Acknowledgements. The author expresses a deep gratitude to the Organizing Team of ICOSS (International Conference on Social Sciences) of Universitas Warmadewa on the great contribution provided to the manuscript publication. More importantly, I thank the Publishing Team of EAI Publisher for the massive concern put on the article processing for an online publication.

\section{References}

[1] Ardhana, I, P, G.: Kajian Kerusakan Sumberdaya Hutan Akibat Kegiatan Pertambangan. Ecotrophic J. Environ. Sci. Vol. 6 (2). pp. 87-93 (2011)

[2] Agribisnis, P. S., Pertanian, F., Udayana, U and Sudirman, J. P. B.: Perilaku Masyarakat dalam Pemeliharaan Hutan Lindung di Banjar Kedisan, Kabupaten Jembrana. Vol. 5 (1). (2016)

[3] Lugina, M., Alviya, I., Indartik, I and Pribadi, M, A.: Strategi Keberlanjutan Pengelolaan Hutan Mangrove di Tahura Ngurah Rai Bali. J. Anal. Kebijak. Kehutan. Vol. 14 (1). pp. 61-77 (2017) [4] Setyarso, A.: Forest Management in Indonesia, Illegal Logging and Associated Trade, FLEGT, VPA, SVLK, and Forest Management Unit (KPH) for the Future of Indonesia Forestry. Yogyakarta. (2016) 
[5] Presiden Republik Indonesa. Undang-Undang Republik Indonesia No. 5 Tahun 1960 tentang Peraturan Dasar Pokok-Pokok Agraria. pp 16 (1960)

[6] Suwitra, I, M., Sukandia, I, N., Widyantara, I, M, M and Nandiri, N, P, S.: Model Pendaftaran Hak Atas Tanah Pauman Sebagai Pemberian Raja untuk Pelestarian Warisan Nilai Budaya di Kabupaten Karangasem. Padjadjaran J. Ilmu Huk. (Journal Law). Vol. 4 (2). pp. 399-418 (2017)

[7] Pemerintah Provinsi Bali.: Peraturan Daerah Propinsi Bali Nomor 3 Tahun 2001 Tentang Desa Pakraman. 3 Tahun 2001, 2001.

[8] Presiden Republik Indonesia. Undang-Undang Republik Indonesia Nomor 41 Tahun 1999 Tentang Kehutanan. pp. 25 (1999)

[9] Ministry of National Development Planning/National Development Planning Agency. National Medium Term Development Plan 2015-2019. Republic of Indonesia. pp. 313. (2015)

[10] Badan Pusat Statistik.: Luas Kawasa Hutan di Provinsi Bali Tahun 2017. Denpasar (2017)

[11] Titian.: Sosialisasi Bentuk-bentuk Perhutanan Sosial (Hutan Desa) di Wilayah KPHP Model Merakai Kabupaten Sintang (2016)

[12] Kementrian Kehutanan Republik Indonesia. Peraturan Menteri Kehutanan Republik Indonesia Nomor : P.89/Menhut-II/2014. pp. 22 (2014)

[13] Kementrian Kehutanan Republik Indonesia. Peraturan Menteri Lingkungan Hidup Dan Kehutanan Republik Indonesia Nomor P.83/Menlhk/Setjen/Kum.1/10/2016 Tentang Perhutanan Sosial. (2016)

[14] Presiden Republik Indonesia. Undang-Undang Republik Indonesia Nomor 6 Tahun 2014 Tentang Desa. pp 20 (2014)

[15] Kementrian Lingkungan Hidup dan Kehutanan Republik Indonesia.: Ringkasan Analisis Data Pelepasan Pelepasan Kawasan. Jakarta (2016)

[16] Rawls, J.: A Theory Of Justice, Revised edition. Massachusetts: Harvard University Press (1971)

[17] Lebacqz, K.: Six theories of justice: perspectives from philosophical and theological ethics. Augsburg Pub. House (1986) 